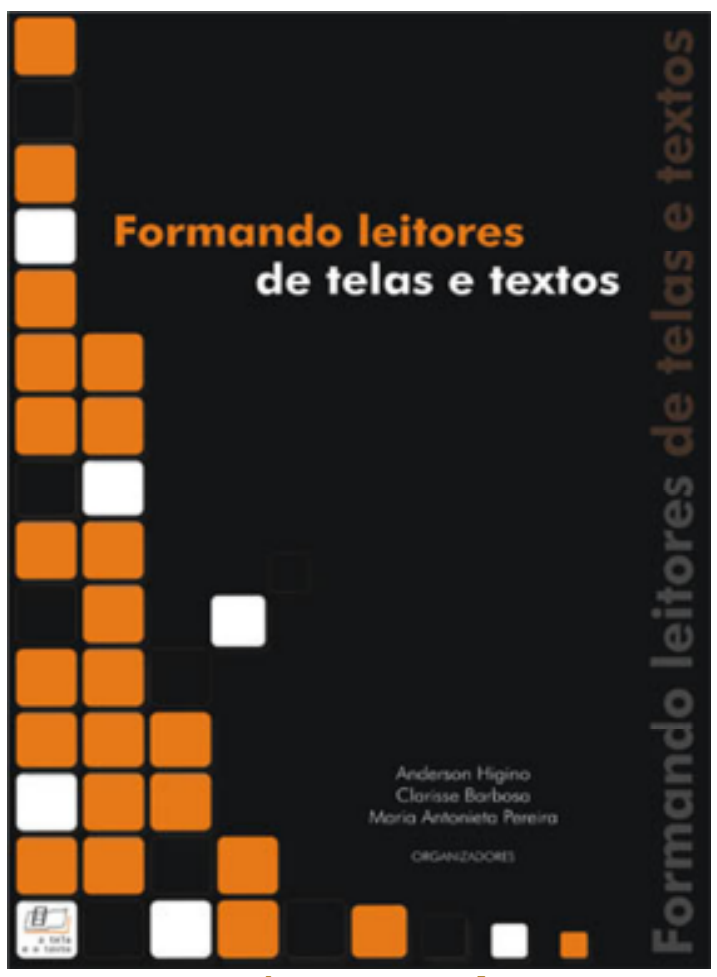

Rubens Rangel

\title{
Formando leitores de telas e textos, o livro
}

\section{Ana Elisa Ribeiro}

Professora do CEFET/MG, doutoranda no Programa de PósGraduação em Estudos Lingüísticos/FALE/UFMG, cronista doDigestivo Cultural.

HIGINO, Anderson, BARBOSA, Clarisse, PEREIRA, Maria Antonieta (orgs.). Formando leitores de telas e textos. Belo Horizonte: Linha Editorial Tela e Texto/FALE/UFMG, 2007.

- programa A tela e o texto acaba de lançar a obra Formando leitores de telas e textos. Organizado pelos professores Anderson Higino, Clarisse Barbosa e Maria Antonieta Pereira, o livro expõe as ações de cada projeto do Programa. São 12 textos que contemplam as diversas faces da formação de leitores. A idéia que parece permear todos os trabalhos é a de que não se considera texto apenas o enunciado lingüistico falado ou escrito, ou seja, nem só de verbos são construídos os textos. 
- capítulo de abertura ficou a cargo de Maria Antonieta Pereira, coordenadora geral do Programa. Em "Leitores e produtores de telas e textos", ela reforça a idéia de que existe, de fato, a necessidade de letrar as pessoas e fazê-las capazes de agir via leitura e escrita. A professora afirma que há "baixíssimos níveis de leitura e escrita no país" e parte desse pressuposto para explicar a existência tão frutífera de um Programa como A tela e o texto, que vem atuando em várias frentes, desde 1998. Além do texto de Maria Antonieta, outros dois são transversais e têm características teóricas mais acentuadas: "Entre telas e textos: contribuições da semiótica greimasiana", da profa. Gláucia Muniz; e "Políticas sociais para uma democrática leitura de textos e telas", do prof. Marcelo Chiaretto, que desperta o leitor para os modos de enxergar e promover a leitura da literatura nas salas de aula.

Os demais capítulos de Formando leitores de telas e textosão amostras de como bons projetos de estímulo à leitura podem ser criados e que razões os levam ao sucesso, tal como acontece com "A leitura como prática dialógica e social", assinado por Cláudia Inácio, Juliana Castro, Lavínia Passos e Maria das Graças Nogueira. O texto mostra como as oficinas de leitura são ministradas e inseridas no dia-a-dia de comunidades na Região Metropolitana de Belo Horizonte. O setor de Mostras e Estudos Audiovisuais tem como missão estimular a leitura de telas de cinema. No texto "O uso didático de obras audiovisuais", Marluce Jácome, Marta Ferreira, Rosilene Souza e Rubens Rangel mencionam as mostras populares, sessões comentadas de filmes, debates em salas de aula, discussões sobre a programação da televisão, entre outras atividades. Da importância da leitura de imagens fotográficas, por sua vez, cuida a profa. Elisa Amorim, no texto "A fotografia e a revelação da auto-imagem". A mediação das câmeras fotográficas parece produzir indivíduos e comunidades mais sensiveis e mais perceptivas em relação ao olhar e aos modos de enxergar a realidade.

O setor de Bibliotecas Comunitárias se faz representar pelo artigo do professor Jairo Rodrigues. No texto "Biblioteca comunitária: conhecimento e cultura construídos em rede", o autor expõe casos de bibliotecas comunitárias e dá dicas para a constituição de outras. Segundo o prof. Jairo, o espaço da biblioteca não é mais entendido como a seara do livro e do silêncio, mas também como um lugar de animação cultural, com a formação de leitores acontecendo não apenas pelo empréstimo de obras.

- Programa A tela de o texto abriga o grupo Contar-te, cujo trabalho é disseminar o gosto pela leitura a partir da apresentação oral de obras literárias. Em "A formação de leitores a partir da contação de histórias", João Paulo da 
Silva, Olívia Abreu, Sandro de Souza e Tainá Ferreira apresentam as formas que encontraram de fisgar leitores. E se não for pelos ouvidos, a literatura pode aparecer diante dos olhos do leitor desavisado, a qualquer momento, na volta do trabalho ou no horário do almoço. Dentro de lâminas cuidadosamente projetadas, poemas e contos de autores conhecidos ou não, contemporâneos ou já em domínio público são expostos ao público usuário de algumas linhas de ônibus pelo projeto Leitura para todos. Cláudia Inácio, Maria Antonieta Pereira, Nárli Machado e Tainá Ferreira apresentam a bela e ousada trajetória de um dos mais simpáticos projetos do Programa no texto "Leitura para todos: uma viagem literária".

O setor da página eletrônica do programa $A$ tela e o texto se mostra no capítulo "Possibilidades da educação virtual: página e revista eletrônicas". Camila Victral, Juliana Castro, Maria Antonieta Pereira, Maria da Conceição Bicalho e Rubens Rangel apresentam a revista txt-leituras transdisciplinares de telas e textos e outros projetos do Programa $A$ tela e o texto responsáveis pela sistematização e pela disponibilização de dados, artigos e resultados dos projetos.

Numa discussão sobre a formação de leitores no Brasil, não pode faltar o tema do acesso ao livro. Maria Magda Santiago, do setor da Linha Editorial Tela e Texto, expõe a história e as ações do projeto que produz livros vendidos a $\mathrm{R} \$ 1,99$. Desmistificar o objeto livro e levá-lo ao leitor com custo baixo, sem perder a qualidade, são alguns dos desafios desse setor. E essas discussões podem acontecer no Fórum de Ensino de Leitura, projeto responsável por promover debates quinzenais, coordenados pelo prof. Anderson Higino.

A idéia que parece atravessar a obra Formando leitores de telas e textos é a de que o Brasil é um país de poucos leitores, ao menos bem menos do que o desejável. Levando-se também em consideração a existência de numeroso contingente de "analfabetos funcionais", um programa como A tela e o texto, representado por tantas frentes de trabalho que empreendem projetos como os apresentados é, certamente, um mobilizador e um transformador de realidades. Outra idéia transversal à obra é aquela segundo a qual a leitura é um bem cultural inacessível ao cidadão em razão de ser cara e pouco disseminada. As ações do Programa em direção à melhora desse quadro são bastante incisivas: oficinas ministradas dentro das comunidades, bibliotecas geridas pelos grupos que delas tiram proveito, a literatura embaixo do nariz do leitor, o livro muito barato, as mostras de cinema na rua. Além disso, a oportunidade da história que entra pelos ouvidos, antes de chegar aos olhos, o chamariz do leitor. $E$ também a oportunidade do debate e da avaliação das ações. 
A obra Formando leitores de telas e textos oferece exemplos de empreendedorismo e ação cultural e deve figurar na lista das bibliografias básicas da formação de professores e de gestores culturais. Cada projeto é um bom exemplo de como criar um efeito disseminador que comece com as pequenas ações e possa alcançar a todos. 